\title{
The use of a food supplement is associated with changes in total cholesterol levels in adult women
}

\author{
Alterações nos níveis de colesterol total em mulheres adultas estão associadas a um \\ suplemento alimentar
}

\section{Nelson Rodrigues Tavares}

CBIOS (Research Center for Biosciences and Health Technologies), Universidade Lusófona de Humanidade e Tecnologias, Campo Grande 376, 1649-024 Lisboa, PORTUGAL

Email: nelson.tavares@ulusofona.pt

\begin{abstract}
High levels of total cholesterol are a significant risk factor for cardiovascular disease. An oral formulation comprised of two types of capsules was tested in adult women $(\mathrm{n}=14)$ with total cholesterol values $>200 \mathrm{mg} /$ $\mathrm{dL}$. In the first capsule were red yeast rice extract, pyridoxine hydrochloride, riboflavin, pteroylglutamic acid and cyanocobalamin, and in the second, a mixture of fish oils containing docosahexaenoic acid and eicosapentaenoic acid. After four weeks of supplementation, a significant $(\mathrm{p}=0.001)$ decrease was observed in the mean values of total cholesterol.
\end{abstract}

Keywords: Hypercholesterolemia, Red yeast rice, Pyridoxine hydrochloride, Riboflavin, Pteroylglutamic acid and Cyanocobalamin

\section{Resumo}

Níveis elevados de colesterol total são um factor de risco significativo para as doenças cardiovasculares. Uma formulação oral, constituída por dois tipos de cápsulas, contendo as primeiras: Extrato de Arroz vermelho fermentado, Cloridrato de piridoxina, Riboflavina, Ácido pteroilglutâmico e Cianocobalamina, e as segundas: uma mistura de óleos de peixe com Ácido docosahexaenóico e Ácido Eicosapentaenóico, foi testada em mulheres adultas $(\mathrm{n}=14)$ com valores de colesterol total $>200 \mathrm{mg} / \mathrm{dL}$. Após 4 semanas de suplementação, foi observada uma diminuição nos valores médios de colesterol total. O consumo desta formulação, ao longo de 4 semanas, reduziu significativamente $(\mathrm{p}=0,001)$ neste grupo de mulheres, os níveis elevados de colesterol total.

Palavras-chave: Hipercolesterolémia, Arroz vermelho fermentado, Cloridrato de piridoxina, Riboflavina, Ácido pteroilglutâmico, Cianocobalamina 


\section{Introduction}

An increased serum cholesterol level has been implicated as a major risk factor for coronary artery disease, and lipid-lowering drugs are extensively used to modify this risk factor. The majority of the evidence has shown that lowering serum cholesterol reduces the risk of cardiac morbidity and mortality. ${ }^{1}$

The current mainstream of lipid-lowering therapy utilizes 3-hydroxy-3-methylglutaryl-coezyme A (HMG$\mathrm{CoA}$ ) reductase inhibitor medications (commonly known as statins) which lower serum cholesterol levels. The available evidence clearly shows that HMGCoA reductase inhibitors reduce the morbidity associated with strokes in patients at increased risk of cardiac events. Data from thirteen placebo-controlled trials suggest that on average one stroke is prevented for every 143 patients treated with statins over a four-year period. $^{2}$

Muscle problems and other adverse symptoms associated with statin use are frequent reasons for non-adherence and discontinuation of statin therapy, resulting in inadequate control of hyperlipidemia and increased cardiovascular risk. ${ }^{3}$ The risk of these adverse effects increases with age. ${ }^{4}$

Red yeast rice (RYR) is a fermented product used as a food supplement to promote blood circulation and lower blood cholesterol levels in eastern Asia. Interestingly, monacolin $\mathrm{K}$ is the most active compound in RYR proven to inhibit HMG-CoA reductase in the cholesterol biosynthesis pathway. ${ }^{5} \mathrm{~A}$ daily intake of $10 \mathrm{mg}$ monacolin $\mathrm{K}$ from any red yeast rice preparation has been reported to be effective for maintenance of normal blood LDL-cholesterol concentrations previously assessed with a favourable outcome by EFSA. ${ }^{6}$ Hyperhomocysteinemia is associated with dysfunction and is an independent risk factor of cardiovascular diseases. ${ }^{7}$ Deficiencies of folate, vitamin B6 and vitamin B12 lead to impaired remethylation of homocysteine causing elevations in plasma homocysteine. ${ }^{8}$ Riboflavin can also contribute to low homocysteine levels. ${ }^{9}$ Consumption of $n-3$ fatty acids from fish oils can contribute to the decrease of triglycerides and LDL-C concentrations. ${ }^{10}$ The present study aimed to investigate the changes on cholesterol levels in subjects from the Lisbon metropolitan area after supplementation for four weeks with a food supplement currently commercialized in dietetic shops and pharmacies.

\section{Introdução}

O aumento dos níveis de colesterol sérico tem sido apontado como um importante fator de risco para a doença coronária. Medicamentos antidislipidémicos, são amplamente utilizados para modificar esse fator de risco. As evidências demonstram que a redução do colesterol, reduz o risco de morbilidade e mortalidade cardíaca. ${ }^{1}$

A corrente principal de terapia para redução dos níveis elevados de colesterol utiliza medicamentos inibidores da enzima 3-hidroxi-3-metilglutaril-coezyme A (HMG-CoA) redutase (comummente conhecidas como estatinas). As evidências disponíveis mostram claramente que os inibidores da HMG-CoA redutase reduzem a morbilidade associada a acidentes vasculares cerebrais em pacientes com risco aumentado de eventos cardíacos. Os dados de 13 ensaios controlados com placebo, sugerem que em média um acidente vascular cerebral é impedido por cada 143 pacientes tratados com estatinas durante um período 4 anos. $^{2}$

Problemas musculares e outros sintomas adversos associados ao uso de estatinas são motivos frequentes para a não-adesão e descontinuação da terapia com estatinas, o que resulta no controle inadequado da hiperlipidemia e aumento do risco cardiovascular. ${ }^{3} \mathrm{O}$ risco desses efeitos adversos aumenta com idade. ${ }^{4}$

A Levedura de arroz vermelho (LAV) é um produto fermentado utilizado no leste da Ásia, como suplemento alimentar para promover a circulação sanguínea e níveis mais baixos de colesterol no sangue. Curiosamente, a monacolina $\mathrm{K}$ é o composto mais activo na LAV que mostrou ter a capacidade de inibir a atividade da HMG-CoA redutase na via metabólica da biossíntese do colesterol. ${ }^{5}$

A ingestão diária de $10 \mathrm{mg}$ monacolina $\mathrm{K}$ a partir de qualquer preparação de levedura de arroz vermelho é a necessária para a manutenção de concentrações normais de colesterol LDL no sangue. Esta alegação de saúde foi avaliada e aprovada favoravelmente pela EFSA. ${ }^{6}$

A hiperhomocisteinemia está associada com disfunção e é um fator de risco independente das doenças cardiovasculares. ${ }^{7}$ As deficiências em folato, vitamina B6 e vitamina $\mathrm{B} 12$ podem conduzir à remetilação ineficaz da homocisteína causando elevações de homocisteína plasmática. ${ }^{8}$ A Riboflavina pode contribuir também para a redução dos níveis elevados de homocisteína. ${ }^{9} \mathrm{O}$ consumo de ácidos gordos n-3 ácidos de óleos de peixe pode contribuir para diminuir as concentrações de colesterol e triglicéridos. ${ }^{10}$

O presente estudo tem como objectivo investigar, num grupo de indivíduos da região metropolitana de Lisboa as alterações nos níveis de colesterol total, após a administração durante 4 semanas de um suplemento alimentar correntemente comercializado em farmácias e dietéticas. 


\section{Material and Methods}

Fifty-four adults, men and women, in the metropolitan area of Lisbon were interviewed by a dietician and a pharmacist in Lisbon, Cascais and Odivelas, between April and May 2015. All participants were informed about the objectives of the study and the risks involved in the protocol. The study was designed and conducted in accordance with the provisions in the latest revision of the Helsinki Declaration ${ }^{11}$. Informed consent was obtained from all volunteers before the start of the test. Inclusion criteria were age $>18$ years, total cholesterol $>200 \mathrm{mg} / \mathrm{dL}$, non-use of medicinal products inhibiting HMG-CoA or other active ingredient that promote the reduction of total cholesterol, and participants who do not repeated blood test after four weeks of supplementation. Total cholesterol was determined by blood test performed with Multicare In Meter Compl apparatus using a drop of capillary blood obtained by pricking the finger quickly and painlessly. The blood droplet was applied as appropriate to a test strip and inserted into the apparatus.

All participants were asked weight and height (used to determine body mass index), physical exercise level (considered only for values greater than 150 minutes per week), if they had hypertension or were taking medication to control hypertension, if they were diabetic, if they had hypothyroidism, whether or not they were smokers ( 1 to 14 cigarette per day) or had a family history of hypocholesterolemia.

A food supplement, comprising two types of capsules, currently sold in pharmacies and food stores in Portugal was provided. The first capsule was taken once daily at dinner and included $400 \mathrm{mg}$ red yeast rice extract (citrinin free) containing $10 \mathrm{mg}$ monacolin $\mathrm{K}$, and 1.4 $\mathrm{mg}$ pyridoxine hydrochloride, $1.4 \mathrm{mg}$ riboflavin, 200 mg pteroylglutamic acid, $2.5 \mu \mathrm{g}$ cyanocobalamin. and taken once daily at dinner, and The second capsule contained $1000 \mathrm{~g}$ of a mixture of fish oils, including 300 mg eicosapentaenoic acid and $190 \mathrm{mg}$ docosahexaenoic acid, and was taken once a day at lunch. The supplement was taken for four weeks.

The statistical analyses were carried out with SPSS 22.0 for Windows (SPSS Inc., an IBM company, Chicago, IL, USA). Total cholesterol variable normality was determined by Shapiro-Wilk Test. The Wilcoxon test was used to establish the significance of response to intervention considering $\mathrm{p}$ value $<0.05$ significant. All study participants ingested capsules according to the established study design and confirmed adherence to the treatment by counting the number of remaining capsules.

\section{Materiais e Métodos}

Cinquenta e quatro adultos, de ambos os sexos, da área metropolitana de Lisboa foram entrevistados por uma dietista e uma farmacêutica em farmácias e dietéticas em Lisboa, Cascais e Odivelas, entre Abril e Maio de 2015. Todos os participantes foram informados acerca dos objectivos do estudo e os riscos envolvidos no protocolo. O estudo foi desenhado e conduzido de acordo com o previsto na última revisão da Declaração de Helsínquia ${ }^{11}$. O Termo de Consentimento Livre e Esclarecido de todos os voluntários foi obtido antes do início do ensaio. Os critérios de inclusão no estudo incluíram a idade $>18$ anos, níveis de colesterol total $>200 \mathrm{mg} / \mathrm{dL}$, a não utilização de medicamentos inibidores da HMG-CoA redutase ou quaisquer outros princípios ativos que promovessem a diminuição do colesterol total, e participantes que não repetissem o teste sanguíneo após 4 semanas de suplementação. O colesterol total foi determinado através de teste sanguíneo realizado com o aparelho Multicare In Meter Compl, utilizando apenas uma gota de sangue capilar, obtida por picada rápida e indolor no dedo, que foi aplicada em tira apropriada e inserida no aparelho. Foi inquirido a todos os participantes: o peso e a altura (utilizados para a determinação do índice de massa corporal), a prática de exercício físico (considerado apenas para valores superiores a 150 minutos por semana), se eram hipertensos ou tomavam medicação para controlar a hipertensão, se eram diabéticos, tinham hipotiroidismo, se eram fumadores ( 1 a 14 cigarros por dia) e tinham história familiar de hipocolesterolémia.

Um suplemento alimentar, constituído por dois tipos de cápsulas, actualmente vendido em farmácias e dietéticas em Portugal que contém por cápsula, as primeiras: $400 \mathrm{mg}$ de Extrato de Arroz vermelho fermentado (isento de citrinina) contendo $10 \mathrm{mg}$ de monacolinas $\mathrm{K}$ e, Cloridrato de piridoxina 1,4 mg, Riboflavina $1,4 \mathrm{mg}$, Ácido pteroilglutâmico $200 \mathrm{mg}$, Cianocobalamina 2,5 $\mu \mathrm{g}$; e tomado uma vez por dia ao jantar e, as segundas: $1000 \mathrm{~g}$ de uma mistura de óleos de peixe com $190 \mathrm{mg}$ de Ácido docosahexaenóico e $300 \mathrm{mg}$ de Ácido Eicosapentaenóico, tomada uma vez por dia ao almoço. O suplemento foi tomado durante quatro semanas.

A análise estatistica foi realizada com o programa SPSS 22.0 para Windows (SPSS Inc., uma empresa do grupo IBM, Chicago, IL, EUA). A normalidade da variável colesterol total foi determinada com o teste de Shapiro-Wilk. O teste de Wilcoxon foi aplicado para estabelecer o significado das diferenças dos valores iniciais e finais da intervenção considerando o valor de $p$ significativo, quando $<0.05$. Todas as participantes no estudo ingeriram as cápsulas de acordo com o estabelecido, tendo sido verificado a adesão ao tratamento através da contagem do número de cápsulas remanescente. 


\section{Results}

Fourteen subjects completed the study. All were Caucasian women. The group had an average age of 53.4 years (33 - 75 years old), and all had elevated levels of total cholesterol. The demographics of the volunteers obtained at baseline are described in Table 1. Results regarding the total cholesterol levels after four weeks supplementation are described in figure 1 and were considered statistically significant, $p=0,001$, at the end of the study.

\section{Resultados}

Concluiram o estudo catorze voluntárias. Todas mulheres caucasianas. Trinta indivíduos não repetiram o teste sanguíneo após 4 semanas de suplementação e dez utilizavam medicamentos inibidores da HMG-CoA redutase.

O grupo apresentou um valor médio de idade de 53,4 anos (33-75 anos), e todas as mulheres apresentavam níveis elevados de colesterol total. Os dados demográficos das voluntárias obtidos no início do estudo estão descritos na Tabela 1. Os resultados obtidos referentes aos níveis do colesterol total estão descritos na figura 1 e são considerados estatisticamente significativos, $\mathrm{p}=0,001$.

No final do estudo foram observadas diferenças estatisticamente significativas dos níveis de colesterol total.

Table 1/ Tabela 1. Subjects demographics

Dados demográficos das participantes

\begin{tabular}{|c|c|}
\hline $\begin{array}{l}\text { Variable } \\
\text { Variável }\end{array}$ & $\begin{array}{l}\text { Group / Grupo } \\
\mathrm{n}=14\end{array}$ \\
\hline $\begin{array}{l}\text { Body Mass Index }\left(\mathrm{kg} / \mathrm{m}^{2}\right) \\
\text { Indice de Massa Corporal }\end{array}$ & $26.9 \pm 0.73^{\mathrm{a}}$ \\
\hline Normal weight/ Peso normal & $28.6 \%$ \\
\hline Overweight/ Excesso de peso & $57.1 \%$ \\
\hline Obesity/ Obesidade & $14.3 \%$ \\
\hline $\begin{array}{l}\text { Age (years) } \\
\text { Idade (anos) }\end{array}$ & $53.4 \pm 11.8^{\mathrm{a}}$ \\
\hline $\begin{array}{l}\text { No or low }<150 \text { min per week exercise } \\
\text { Não pratica ou realiza }<150 \text { min de exercício por semana }\end{array}$ & $100 \%$ \\
\hline $\begin{array}{l}\text { Hypertension (systolic blood pressure/diastolic blood pressure>140/80) } \\
\text { Hipertensão (pressão arterial sistólica/pressão arterial diastólica >140/80) }\end{array}$ & $28.6 \%$ \\
\hline $\begin{array}{l}\text { Antihypertensive medication } \\
\text { Medicamentos anti-hipertensores }\end{array}$ & $21.4 \%$ \\
\hline Diabetes & $0 \%$ \\
\hline $\begin{array}{l}\text { Hypothyroidism } \\
\text { Hipotiroidismo }\end{array}$ & $0 \%$ \\
\hline $\begin{array}{l}\text { Smoking } \\
\text { Fumar }\end{array}$ & $14.3 \%$ \\
\hline $\begin{array}{l}\text { Family history of elevated cholesterol } \\
\text { História familiar de hipercolesterolémia }\end{array}$ & $78.6 \%$ \\
\hline
\end{tabular}

${ }^{\text {a }}$ Values are mean \pm SD

Valores médios + dp 
Colesterol Total mg/dL

Total Cholesterol mg/dL

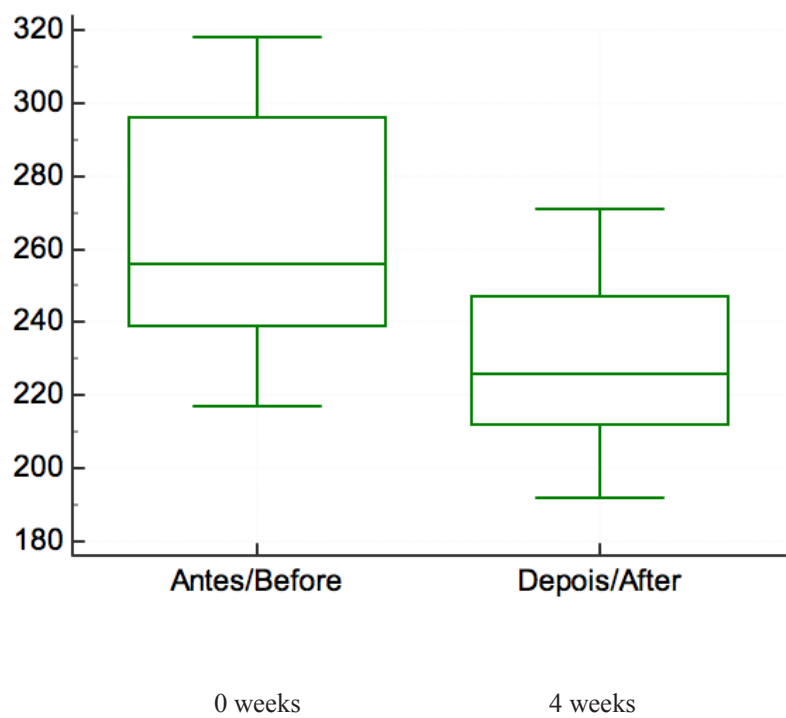

Response to intervention determined with the Wilcoxon Signed Rank test $(\mathrm{p}<0.05$ considered statistically significant)

/ Resposta à intervenção determinada com o teste de Wilcoxon $(\mathrm{p}<0,05$ considerado estatisticamente significativo)

Figure 1/ Figura 1. Total cholesterol variation before and after four weeks supplementation Variação de colesterol total antes e após 4 semanas de suplementação

\section{Discussion}

The total cholesterol values were decreased significantly after supplementation. With the formulation that comprises two types of capsules: the first, red yeast rice extract (citrinin free) containing $10 \mathrm{mg}$ monacolinas K, $1.4 \mathrm{mg}$ pyridoxine hydrochloride, $1.4 \mathrm{mg}$ riboflavin, $200 \mathrm{mg}$ pteroylglutamic acid, and $2.5 \mu \mathrm{g}$ cyanocobalamin, taken once daily at dinner; the second containing $1000 \mathrm{mg}$ of a mixture of fish oils containing eicosapentaenoic acid and docosahexaenoic acid, taken once per day at lunch. The supplement was taken during four weeks by women with values $>200 \mathrm{mg} / \mathrm{dL}$ of total cholesterol. None of the participants reported the existence of muscle pain during the period in which supplementation was used.

The results obtained are similar to previous studies. In one study, a dietary supplement with RYR in combination with a balanced diet and physical exercise was found to induce a significant reduction in total cholesterol. ${ }^{12}$ In another study, a dietary supplement was prepared from rice fermented with red yeast (Monascus purpureus), which has been shown to significantly decrease total cholesterol levels in hyperlipidemic subjects. ${ }^{13}$

\section{Discussão}

Os valores de colesterol total foram alterados após a suplementação com a formulação constituída por dois tipos de cápsulas, as primeiras: Extrato de Arroz vermelho fermentado (isento de citrinina) contendo 10 mg de monacolinas $\mathrm{K}$, Cloridrato de piridoxina 1,4 $\mathrm{mg}$, Riboflavina 1,4 mg, Ácido pteroilglutâmico 200 mg e Cianocobalamina 2,5 $\mu \mathrm{g}$; e tomado uma vez por dia ao jantar e, as segundas: $1000 \mathrm{~g}$ de uma mistura de óleos de peixe com ácido docosahexaenóico e ácido eicosapentaenóico, tomada uma vez por dia ao almoço. O suplemento foi tomado durante quatro semanas, por mulheres com valores $>200 \mathrm{mg} / \mathrm{dL}$ de colesterol total. A redução dos níveis de colesterol total foi obtido sem qualquer restrição calórica. Nenhuma das participantes relatou a existência de dores musculares durante o período em que efectuou a suplementação.

Os resultados obtidos são semelhantes aos de outros estudos anteriores. Num estudo em que foi utilizado um suplemento alimentar com RYR em combinação com uma dieta equilibrada e exercício físico, foi induzida uma redução significativa no colesterol total. ${ }^{12}$. Noutro estudo um suplemento dietético, foi preparado a partir 
Considering exercise and smoking as cardiovascular risk factors, the results showed that the participants do not undertake or practice more than 150 minutes per week for physical fitness. In a study of overweight and obese adults to measure the effect of regular exercise on cardiometabolic markers including total cholesterol, levels of this marker remained unchanged after six and twelve months. ${ }^{14}$ The amount and duration of smoking is associated with worsening of total cholesterol. ${ }^{15}$ The percentage of women identified as smokers in this study was $14.3 \%$.

The diuretics and adrenergic blocking agents have been widely used in the treatment of hypertension. Studies have indicated that thiazides and chlorthalidone have an adverse effect on lipid metabolism, increasing total cholesterol in hypertensive patients. ${ }^{16}$ The percentage of women who use antihypertensive drugs in this study was $21.4 \%$.

The results of this study are limited by the small size and duration, and the lack of a control group. The nonevaluation of HDL and LDL cholesterol levels as well as the subjects' food intake can have contribute to less robust results. A statistically significant reduction in total cholesterol should be investigated in a randomized, controlled trial with longer duration of time as well as number of participants.

For clinical practice, reduced or no adverse symptoms associated with supplementation could contribute to the adherence and continuation of therapy, which could result in adequate control of hyperlipidemia and decreased cardiovascular risk.

In conclusion, the results of this study suggest that a supplement can reduce total cholesterol in women with excess weight and elevated cholesterol $(>200 \mathrm{mg} / \mathrm{dL})$ under the conditions described in the study.

\section{Acknowledgements}

The author expresses a deep gratitude to dietitian Inês Rocha and pharmacist Isabel Pereira for their kind cooperation.

\section{Conflict of interests}

The author declares that there are no financial and personal relationships that could be viewed as presenting conflict of interests. de arroz fermentado com levedura vermelha (Monascus purpureus), e reduziu significativamente os níveis de colesterol total em indivíduos hiperlipidémicos. ${ }^{13}$

Considerando os fatores de risco cardiovascular fumar e não prática de exercício físico os resultados mostraram que as participantes não realizam ou não dispendem mais de 150 minutos por semana a praticar exercício físico. Num estudo realizado em adultos com excesso de peso e obesos para medir o efeito do exercício físico regular nos marcadores cardiometabólicos incluindo o colesterol total, os níveis deste marcador mantiveram-se inalterados aos 6 e aos 12 meses. ${ }^{14}$ A quantidade e a duração do hábito de fumar estão associados com o agravamento dos níveis de colesterol total. ${ }^{15} \mathrm{~A}$ percentagem de mulheres fumadoras neste estudo foi de apenas $14,3 \%$.

Os diuréticos e agentes bloqueadores adrenérgicos têm sido amplamente utilizados no tratamento da hipertensão. Estudos têm indicado que as tiazidas e a clorotalidona têm um efeito adverso sobre o metabolismo dos lípidos, por aumento de colesterol total em doentes hipertensos. ${ }^{16}$ A percentagem de mulheres que utilizam medicamentos anti-hipertensores neste estudo foi de apenas $21,4 \%$.

Os resultados deste estudo são limitadas pelo pequeno tamanho e duração, e a falta de um grupo de controlo. O colesterol HDL e LDL não avaliação, bem como a ingestão de alimentos pode contribuiu para resultados menos robustos. A redução estatisticamente significativa no colesterol total deve ser investigada em um estudo randomizado, controlado com maior duração de tempo, bem como número de participantes. Para a prática clínica reduzida ou nenhuma sintomas adversos associados com a suplementação poderia contribuir para a aderência e a continuação da terapia, o que resulta em adequado controle da hiperlipidemia e diminuição do risco cardiovascular.

Em conclusão, os resultados deste estudo sugerem que um suplemento pode efectivamente reduzir o colesterol total $>200 \mathrm{mg} / \mathrm{dL}$ em mulheres com excesso de peso, nas condições descritas no estudo.

\section{Agradecimentos}

$\mathrm{O}$ autor expressa os seus profundos agradecimentos à dietista Inês Rocha e à farmacêutica Isabel Pereira pela colaboração.

\section{Conflito de interesses}

$\mathrm{O}$ autor declara que não existem quaisquer relações pessoais ou financeiras que possam ser vistas como um potencial conflito de interesses no presente estudo. 


\section{References/ Referências}

1. Grundy SM, et al. (1997). Cholesterol and coronary heart disease: the 21stcentury. Arch Intern Med. 1997;157:1177-84.

2. Warshafsky, S., Packard, D., Marks, S. J., Sachdeva, N., Terashita, D. M., Kaufman, G., ... Frishman, W. H. (1999). Efficacy of 3-Hydroxy-3-Methylglutaryl Coenzyme A Reductase Inhibitors for Prevention of Stroke. Journal of General Internal Medicine, 14(12), 763-774. http://doi.org/10.1046/ j.1525-1497.1999.02109.x

3. Stulc T, Ceška R, Gotto AM Jr. (2015). Statin Intolerance: the Clinician's Perspective. Curr Atheroscler Rep. 17:69. doi: 10.1007/ s11883-015-0552-3

4. Golomb B, Evans M. (2008). Statin adverse effects: a review of the literature and evidence for a mitochondrial mechanism. Am J Cardiovase Drugs. 8:373-418.

5. Bunnoy A, Saenphet K, Lumyong S, Saenphet S, Chomdej S. Monascus purpureusfermented Thai glutinous rice reduces blood and hepatic cholesterol and hepatic steatosis concentrations in diet-induced hypercholesterolemic rats. BMC Complement Altern Med. 2015 Mar 28;15:88. doi: 10.1186/ s12906-015-0624-5.

6. EFSA Panel on Dietetic Products Nutrition and Allergies (NDA), 2001. Scientific Opinion on the substantiation of health claims related to monacolin $\mathrm{K}$ from red yeast rice and maintenance of normal blood LDL cholesterol concentrations (ID 1648, 1700) pursuant to Article 13(1) of Regulation (EC) No 1924/2006. EFSA Journal, 9(7):2304, 16pp.
7. Lin CP1, Chen YH, Chen JW, Leu HB, Liu TZ, Liu PL, Huang SL.Cholestin (Monascus purpureus rice) inhibits homocysteineinduced reactive oxygen species generation, nuclear factor-kappaB activation, and vascular cell adhesion molecule-1 expression in human aortic endothelial cells. Biomed Sci. 2008; 15:183-96

8. Miller JW, 2005. Homocysteine. In: Encyclopedia of Human Nutrition. Caballero B, Allen L, Prentice A (eds.). Elsevier, Oxford, 462-469.

9. Tavares, Nelson A. R; Moreira, Pedro A. A. S; Amaral, Teresa M. S. P. F. (2009). Riboflavin supplementation and biomarkers of cardiovascular disease in the elderly. The Journal of Nutrition Health and Aging, 13: 441 - 446.

10. Ras RT, Demonty I, Zebregs YE, Quadt JF, Olsson J, Trautwein EA.(2014). Low doses of eicosapentaenoic acid and docosahexaenoic acid from fish oil dose-dependently decrease serum triglyceride concentrations in the presence of plant sterols in hypercholesterolemic men and women. J Nutr.144:156470

11. World Medical Association Declaration of Helsinki. Fortaleza 2013. In URL: http:// www.wma.net/en/30publications/10policies/ b3/ (accessed 6 April 2015).
12. Lombardo F, Lunghi R, Pallotti F, Palumbo A, Senofonte G, Cefaloni AC, Gandini L, Lenzi A. (2013). Effects of a dietary supplement on cholesterol in subjects with moderate hypercholesterolemia. Clin Ter. 164:e147-50.

13. Man RY, Lynn EG, Cheung F, Tsang PS, O K. (2002). Cholestin inhibits cholesterol synthesis and secretion in hepatic cells (HepG2). Mol Cell Biochem. 2002;233:153-8.

14. Gondim OS, Camargo VTNd, Gutierrez FA, Martins PFdO, Passos MEP, Momesso CM, et al. (2015). Benefits of Regular Exercise on Inflammatory and Cardiovascular Risk Markers in Normal Weight, Overweight and Obese Adults. PLoS ONE 10(10): e0140596. doi:10.1371/journal.pone.0140596

15. Xirofotos D, Trakakis E, Peppa M, et al. 2015. The amount and duration of smoking is associated with aggravation of hormone and biochemical profile in women with PCOS Gynecol Endocrinol. 2015 Oct 28:1-4.

16. Cutler R. 1983. Effect of antihypertensive agents on lipid metabolism. Am J Cardiol. 24;51(4):628-31. 